\title{
Location of two glacier surges in West Greenland
}

\author{
Anker Weidick
}

The registration of West Greenland glaciers was completed in 1983. Around 5000 local glaciers and lobes from the Inland Ice have been located. Indications of surging behaviour have been noted at a restricted number of these, and the two localities with the best documentation and most peculiar features are described below. One is an example of a 'periodic surge', while the other is essentially a 'permanent surge'.

The main characteristic of glacier surges is a rapid transfer of large volumes of ice from a reservoir area (usually to the snout), so that velocities are 10 to 100 times those of normal glaciers. Rates of movement of surging glaciers usually reach $1 \mathrm{~m}$ or more per day (Paterson, 1981). The strong movement leaves diagnostic features on the glacier surface in the form of chaotic crevassing or looped moraines.

Local glaciers can only provide enough ice to maintain high flow rates for a short time, and the catastrophic advances of such 'periodic surges' are often repeated with reported intervals of 20-100 years.

Since some of the outlets from the Greenland Inland Ice move permanently with high velocities the concept of surging has been extended to cover these cases as well, but as 'permanent surges' (Hughes, 1978; Weertman, 1983). The ice sheet here provides sufficient ice for the permanent maintenance of high flow rates.

\section{Temporary surges}

The location reported is situated in the central part of Disko in Nordfjordspasset mid-way between Disko Fjord and Nordfjord at $69^{\circ} 46^{\prime} \mathrm{N}, 53^{\circ} 59^{\prime} \mathrm{W}$. The glacier has no name but the inventory code $1 \mathrm{HB} 10013$. It fills a south-west facing corrie worked out in basalt. The upper reach of the glacier body proper is about $1000 \mathrm{~m}$ and neoglacial moraines indicate an earlier extent down to $400 \mathrm{~m}$ above sea level. In 1953 the position of the front was at $450 \mathrm{~m}$ above sea level and $200 \mathrm{~m}$ behind the moraines. In part, the glacier is fed from the surrounding ice caps resting on plateau surfaces between 1100 and $1300 \mathrm{~m}$ above sea level.

The earliest information on the glacier is obtained from the plane-table measured maps of 1931-1933 (Geodetic Institute, map sheet 69 V.1, Godhavn). The outline of the glacier on this map shows the glacier snout at $500-600 \mathrm{~m}$ above sea level and a subsequent reduction of the lower parts of the glacier must be supposed since the glacier on aerial photographs taken on 08.08 .1947 is shown with the front situated at $600 \mathrm{~m}$ above sea level. The area of the glacier was $5.8 \mathrm{~km}^{2}$ in $1946,1.2 \mathrm{~km}^{2}$ being sectors of the surrounding ice caps. The surface of the glacier did not exhibit any special features in 1946.

The following information on glacier $1 \mathrm{HB} 10013$ is furnished by aerial photographs of 19.07.1953 and 15.08.1953 (fig. 42). They show a glacier with the surface heavily broken through the total length of the glacier, and also an expansion of the lower parts of the glacier since 1946 of $1 \mathrm{~km}^{2}$. In the same period the glacier front advanced $1 \mathrm{~km}$.

Later aerial photographs taken on 27.08.1964 show the glacier covered by new snow. The front seems to be in the same position as in 1953, but now has moraine cover. 


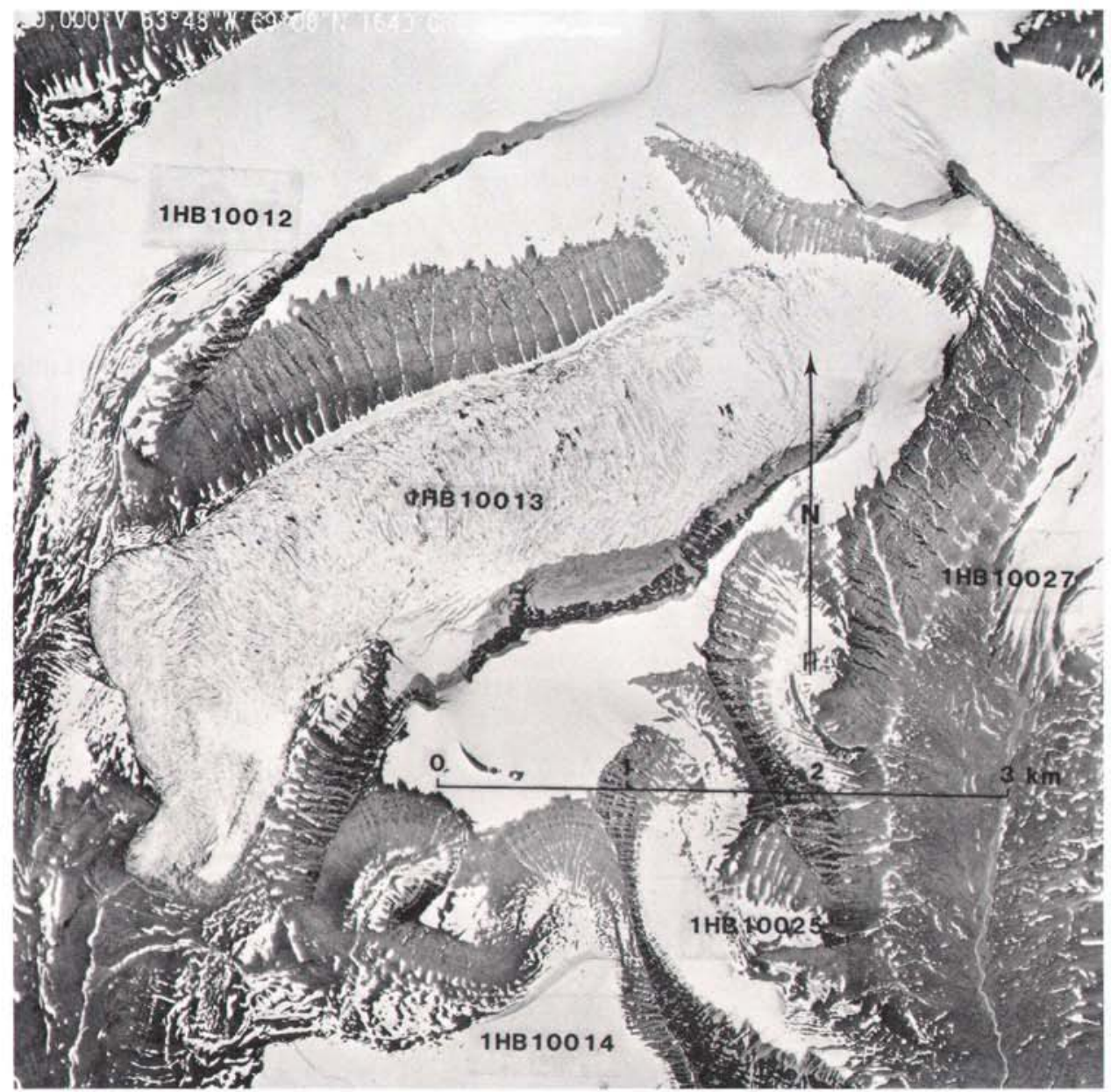

Fig. 42. Glacier 1HB10013, Disko. The chaotic broken surface of the glacier distinguishes it from other glaciers in the area. Aerial photograph of 19th July 1953. Geodetic Institute's route A 93/127 no. 79. Courtesy of the Geodetic Institute, Copenhagen.

A glacier surge undoubtedly took place shortly before 1953 . The glacier might be part of a greater group of surging local glaciers in central Disko (e.g. Sorte Hak and other glaciers in Kuanerssuit valley, $20 \mathrm{~km}$ east of the reported surge) but the other glaciers on the island are not documented to the same extent.

\section{Permanent surges}

At least 11 outlets between $70^{\circ}$ and $68^{\circ} \mathrm{N}$ in West Greenland are moving at rates over $1 \mathrm{~m} / 24 \mathrm{~h}$ which indicates that the main drainage of the ice sheet takes place in Umanak Fjord 


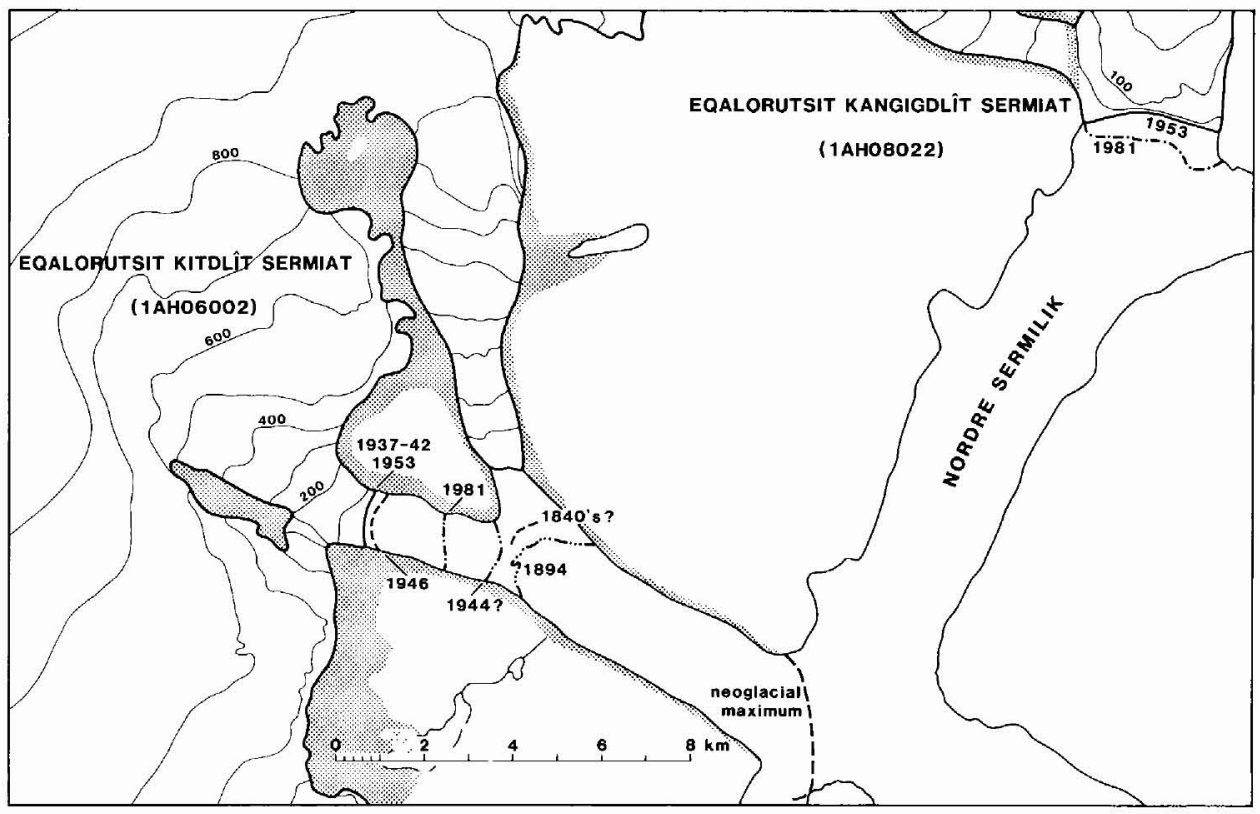

1AH06002 EQALORUTSIT KITDLÎT SERMIAT

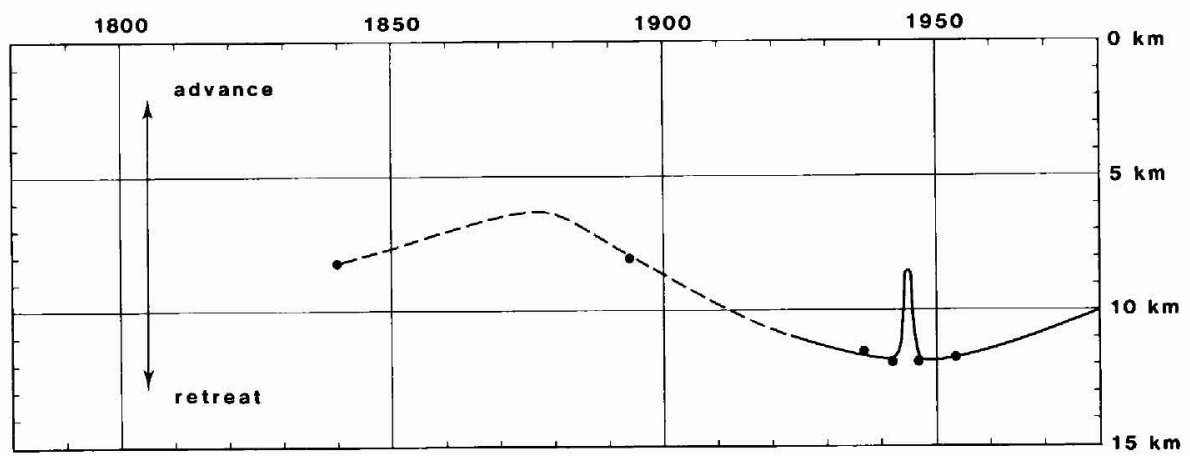

Fig. 43. Top: Sketch map of the fronts of Eqalorutsit kangigdlît sermiat and Eqalorutsit kitdlît sermiat, Nordre Sermilik in South Greenland. Reported front positions indicated. Bottom: Change of front position expressed in distance from neoglacial maximum.

complex and in Disko Bugt, with Jakobshavn Isbræ as a paramount example of a permanent surge, moving at $17 \mathrm{~m} / 24 \mathrm{~h}$.

High rates of movement must also be expected further south in West Greenland in the heads of Godthåbsfjord $\left(64^{\circ} \mathrm{N}\right)$, Sermilik $\left(62^{\circ} \mathrm{N}\right)$, and Nordre Sermilik $\left(61^{\circ} \mathrm{N}\right)$.

In the last locality, a considerable production of calf ice is maintained by two lobes from the south slope of the ice sheet, namely a northern outlet of Eqalorutsit kitdlit sermiat and an eastern outlet of Eqalorutsit kangigdlitt sermiat, both shown on the map fig. 43 . 


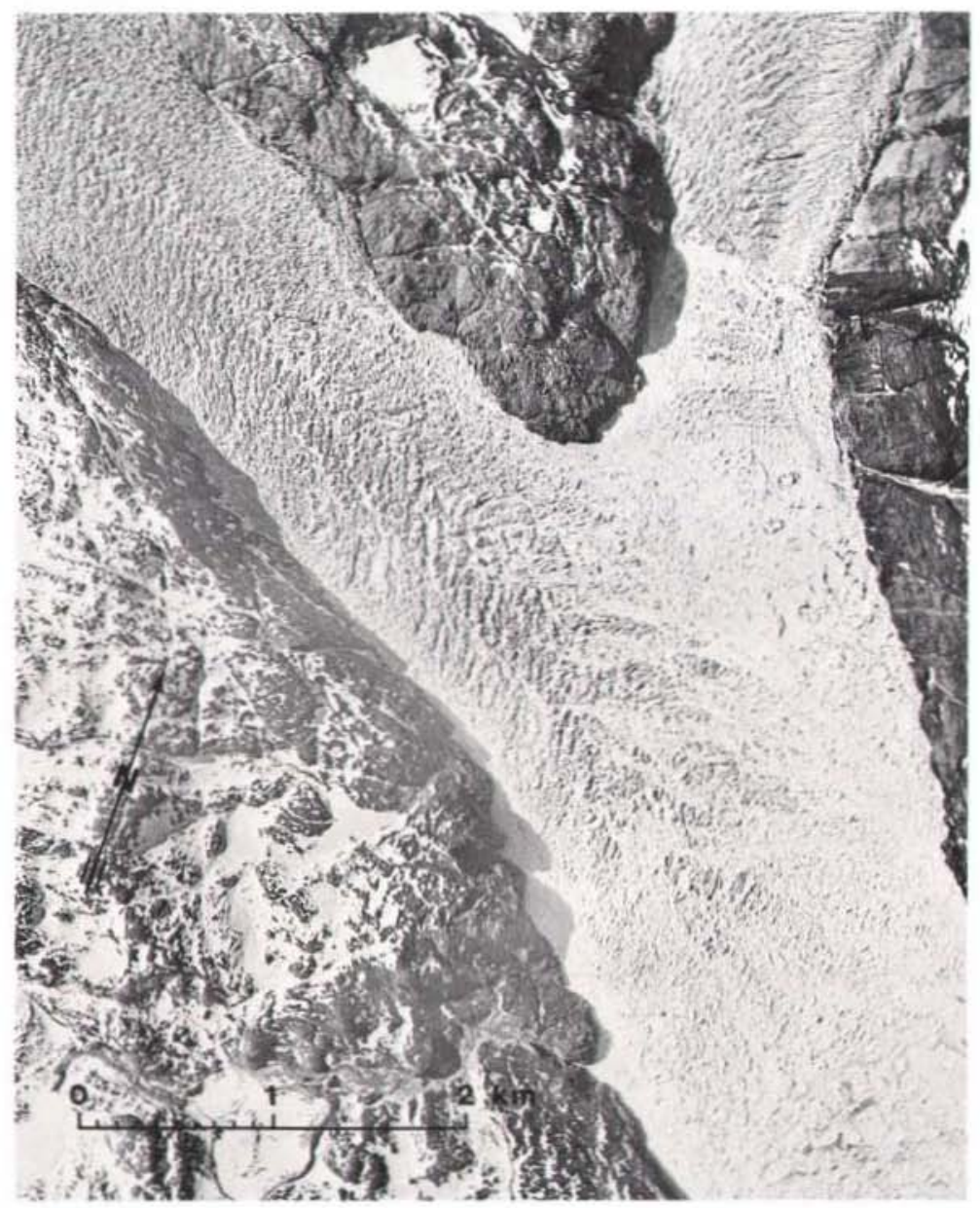

Fig. 44. Frontal situation of Eqalorutsit kitdlit sermiat at around 1944. Determination of position of the glacier front is difficult as it has begun to retreat. Geodetic Institute's route A6B no. 56. Courtesy of the Geodetic Institute, Copenhagen.

The front of Eqalorutsit kangigdlit sermiat is $4 \mathrm{~km}$ wide and the main central crevassed part must be expected to move rapidly at the front (Weidick \& Olesen, 1980). Measured rates of movement $15 \mathrm{~km}$ upstream from the front are around $4.5 \mathrm{~m} / 24 \mathrm{~h}$ (Knudsen, 1983), so the velocity at the front might be around $10 \mathrm{~m} / 24 \mathrm{~h}$. The glacier front has been slightly expanding since 1930 .

The front of Eqalorutsit kitdlit sermiat was originally $2 \mathrm{~km}$ wide but a recession of the front took place, since presumably the 18 th century, $12 \mathrm{~km}$ up the fjord (fig. 43), and the glacier front is now split by a nunatak into two branches, 1 and $1 / 2 \mathrm{~km}$ wide, respectively. Measurements of rate of movement have been made only in connection with the 1894 
investigation (Jessen, 1896) in a profile close to the position of the front of 1981 in fig. 43. Several points moved over $12 \mathrm{~m} / 24 \mathrm{~h}$.

The current change in the frontal position of Eqalorutsit kitdlit sermiat is also shown in fig. 43, indicating a general recession since the 18th century, interrupted by a minor readvance around 1880, and a readvance since the 1950s. This pattern is general for many South Greenland glaciers but the amplitude of the change $(12 \mathrm{~km})$ is exceptional, since frontal changes are mostly between 2 and $4 \mathrm{~km}$. The change of front position of Eqalorutsit kitdlit sermiat is comparable to those of some other fast moving glaciers (outlets) such as Kangiata nunâta sermia in Godthåbsfjord $(20 \mathrm{~km}$ recession), Jakobshavn Isbræ $(26 \mathrm{~km}$ recession), or Upernavik Isstrøm (recession over $20 \mathrm{~km}$ ).

A peculiar feature of the recession curve of Eqalorutsit kitdlit sermiat in fig. 43 is the sudden advance around 1944(?) of at least $4 \mathrm{~km}$. The information is based on aerial photographs taken during the 2nd World War but not dated exactly. Observations from 1942 and 1946, however, show the glacier front in retreated positions, and the advance therefore must be supposed to have taken place shortly after 1942 since the picture (fig. 44) shows the lobe in a retreating phase after the advance. It is unknown whether it is physically possible to have a 'temporary surge' on top of a 'permanent surge', but at least the case illustrates the existence of short pulsations which might often have escaped the former scattered observations on frontal positions. This problem, however, will be overcome in the future by Landsat monitoring.

\section{References}

Hughes, T. 1978: Discussion. In Kotlyakov, V. M. (edit.) Proceeding of the International Workshop on Mechanism of Glacier Variations. Mater. glyatsiol. Issled. 33, 187-188.

Jessen, A. 1896: Geologiske Iagttagelser. In Opmålingsexpeditionen til Julianehaabs Distrikt 1894. Meddr Grønland 16(2), 123-169.

Knudsen, J. T. 1983: Photogrammetric investigations in West Greenland. Rapp. Grønlands geol. Unders. 115, 115-117.

Paterson, W. S. B. 1981: The Physics of Glaciers. 380 pp. London: Pergamon.

Weertman, J. 1983: Workshop on the Jakobshavn Glacier (Greenland). Northwestern University, Evanston, Ill., February 8-10, 1983. 92 pp. National Science Foundation, Grant nr. DPP 82-19132.

Weidick, A. \& Olesen, O. B. 1980: Hydrological basins in West Greenland. Rapp. Grønlands geol. Unders. 94, $51 \mathrm{pp}$. 